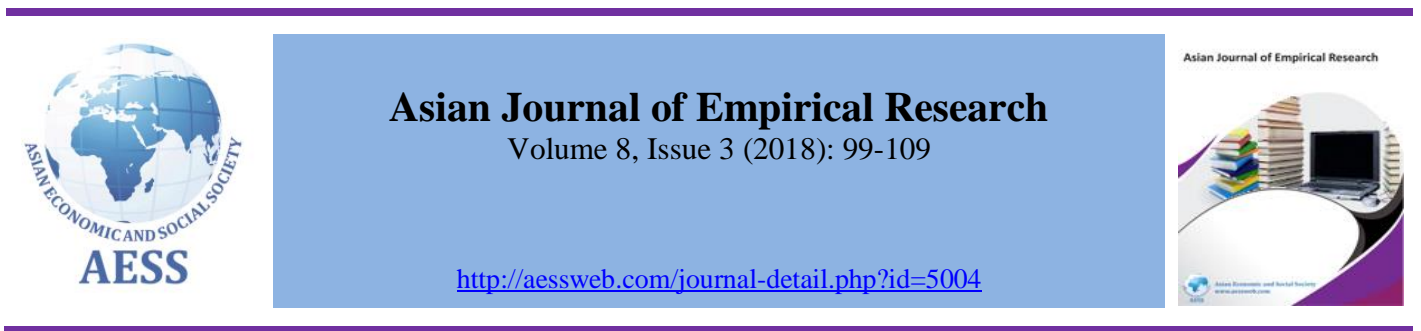

\title{
An empirical investigation of investor's behavioral biases on financial decision making
}

\author{
Imran Umer Chhapra ${ }^{a}$, Muhammad Kashif ${ }^{\mathrm{a}}$, Raja \\ Rehan $^{\text {b }, \text { Ashow Bai }}{ }^{\text {a }}$ \\ ${ }^{a}$ Shaheed Zulfikar Ali Bhutto Institute of Science \& \\ Technology (SZABIST), Karachi, Pakistan. \\ ${ }^{\mathrm{b}}$ University Kuala Lumpur, Malaysia. \\ \Imran_Js@Yahoo.com
}

ARTICLE HISTORY:

Received: 08-Feb-2018

Accepted: 12-Mar-2018

Online available: $02-\mathrm{Apr}-2018$

\section{Keywords:}

Financial decision making,

Behavioral biases,

Pakistan stock exchange

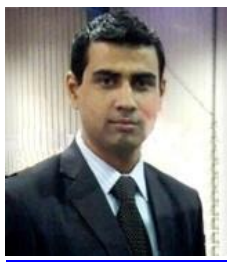

Corresponding author

ABSTRACT

Investor's irrationality is an inevitable reality that has been time and again highlighted by researchers (Statman, 2008). Therefore, this study is another effort to assess the role of behavioral biases in financial decision making in Pakistan Stock Exchange (PSX). A survey questionnaire is designed and used to collect responses using convenience sampling technique from sample of 250 investors of PSX. Behavioral biases include overconfidence, over thinking, herding, cognitive bias, and hindsight effect of investors. Multiple regression models are used to test influence of five behavioral biases on investment decision. The results show that overconfidence, over thinking, herding, cognitive bias, and hindsight effect have significant positive impact on investment decision. Overall results conclude that much change in investment decision is due to behavioral biases. This study will help financial advisors to better advice their clients. The one way to reduce these biases may be education and training of investors.

\section{Contribution/ Originality}

Behavioral finance is a growing phenomenon around the world as it plays a vital role in financial decision making. Previous researchers have found that Asian investors are more prone to behavioral biases as compared to western investors. Therefore, in order develop confidence in the market, and maintain investment stability, this research provides an effective ground to overcome lack of investor discipline and to keep up the market from behavioral anomalies of investor especially in Pakistan.

DOI: 10.18488/journal.1007/2018.7.3/1007.3.99.109

ISSN (P): 2306-983X, ISSN (E): 2224-4425

How to cite: Imran Umer Chhapra, Muhammad Kashif, Raja Rehan and Ashow Bai (2018). An empirical investigation of investor's behavioral biases on financial decision making. Asian Journal of Empirical Research, 8(3), 99-109.

(C) 2018 Asian Economic and Social Society. All rights reserved 


\section{INTRODUCTION}

Investing in financial markets in recent times has become popular not only among institutional but also individual investors. Communications and information have become available worldwide in seconds speed. Investment decisions depend on the data and its financial position in the future, but most of the time short-term price changes are driven by market participants that are not always based on logic but sometimes are inspired by mood or instantly received news.

Human beings are known to make decisions based on their intuitions and feeling rather than collecting sufficient information which will facilitate effective decision making. Researchers have shown that investors make irrational investment decisions. According to Markowitz (1952), investors are rational and risk averse and will prefer low risk to high risk for a given level of return. In the actual market place, investors show irrational behaviors; they trade excessively, purchase stock without considering the fundamental value, base their decisions on past performance, buy stocks which their friends are buying, and retain loss making stocks while selling bullish stocks. The investors make their decision processes simple and are experience to behavioral problems that might cause systematic errors and lead to satisfactory investment choices, but which do not maximize utility (Kahneman and Tverskey, 1979). Behavioral biases have been attributed to the irrationality in decision making. Shefrin (2000) defines bias as the predisposition towards error. Hence, investors show irrational behavior due to interpretation of different situations, wrong judgments and distortion in perception whereas; traditional economics and financial theories consider human being as perfect rational agent (Babajide and Adetiloy, 2012).

Moreover, behavioral economist opposes this concept of perfect rationality and study emotional and psychological factors and their impact on investment decision making. Investment decisions in everyday life depend on combination of different factors like, emotion, reason, habit and social interaction. Research in behavioral finance shed serious doubts on validity of traditional finance theories like efficient markets, portfolio theory and risk-return trade off. Franco Modigliani and Merton Miller work in finance and their assumptions of rational man who maximize utility is no more relevant due to lack of empirical evidences (DeBondt et al., 2013). Standard finance models are based on rationality which implies two things i.e. people update their belief in current manner and make decisions consistent with subjective expected utility theory. The efficient capital market concepts proposed that non-rational investors distort prices while due to arbitrage opportunities, expert traders take full advantage. However, human intuitions and behavioral biases play key role in financial decisions (DeBondt et al., 2013).

Behavioral finance classified in two main components: limits to arbitrage and Psychology. According to the first component, anomalies arise and persist. In an economic world, irrational agents give the chance to rational agents to take advantage and gain money. This phenomenon in the long term leads to the irrational agents to quit the market, and this process is known as arbitrage. In fact, arbitrage is the opportunity that gives profit to economic agents without risk. Therefore, we can conclude that persistent anomalies observed in the market can be the result of irrationality and then limits to arbitrage lead to mispricing (Barberis and Thaler, 2003; Shleifer and Vishny, 1997). As Shleifer and Vishny argued that the efforts of arbitrageurs to make money will make some markets more efficient without having any effect on other markets (Shleifer and Vishny, 1997).

Furthermore, the investor behavior in stock market depends on many factors like investment horizons, other participants' behavior, the performance benchmarks and presence of volatility and speculation in stock markets (Chang et al., 2000). Every investor invests with unique planning or even invests without planning. Basically, majority want high return that will make them rich overnight. They have different choices like they can only buy on fundamental information of their company or on advice of other investors. On the broader side, investors invest on the basis of their available amount of capital, time frame and financial goals (Muhammad and Abdullah, 2009). Lin and Zhang (2012) suggested that investors commit behavioral biases due to lack of technical expertise and confidence on their 
abilities in better decision making about investments (Lin and Zhang, 2012). He studied behavioral biases like Herding, Overconfidence, Hindsight Bias, Cognitive bias and Overreaction and suggested that these behavioral biases have influence on rational decision making. Therefore, investment decision making is linked with these behavioral biases. There are considerable efforts in studying the behavior of investors and its possible impact on prices. Therefore, understanding the factors affecting investment decision making is very important issue in finance.

Pakistan Stock Exchange (PSX) is a major stock exchange in Pakistan. Recently, investors in PSX show resentment over many up and downs in stock market. Many investors blame big investors for manipulation. Therefore, it is important to study investor behavior of individual investors to better develop financial advisory services and make policy foe secure and strong financial systems. Many investors lack technical expertise, knowledge required for investment in stock market. They usually take advice from brokers and other experienced investors. However, a tailor made advice system cannot work in different situations and person characteristics. Therefore, a complete investor profile analysis is needed to advice investor for better decision making. Majority of studies are conducted in developed western countries and they used secondary data. Secondary data did not show opinion of investors as stock market is affected by many other factors. Therefore, it is important to study "whether behavioral biases exist in PSX and what are influences of investor's behavior biases on investment decision making and moderating role of investor's type in PSX.

Behavioral finance combines, insights from psychology economics and finance. This study is an important effort for financial advisory services, finance mangers and risk management executives. This study will help financial advisors to identify the different types of behavioral biases and their possible impact on investment decision making. This study will also help regulatory authorities in securing financial strength and making policies to avoid these biases. It will also help investors to make wise investment decisions. Therefore it is important to study investor behavior of individual and impact of behavioral biases on investment decision making.

\section{LITERATURE REVIEW}

There are many considerations regarding the investors preferences about stocks, as mostly investor prefer to purchase most desirable stocks. Investors selling decisions mostly depend upon winning stocks. On the other hand buying decisions linked with both losing and winning stocks. There are thousands of listed securities and investors usually purchase those stocks in which they have interest and awareness regarding the stocks past performance either bad or good (Odean, 1999). Similarly, selling decisions are easy for individual investors because during the selling decisions they only concentrated on their holding stocks while on the other side buying decisions are quite tricky as they have lots of factors regarding the stock purchase (Barberis and Thaker, 2003).

The field behavioral science in financial disputes is a new incident in financial market studies. This incident discusses that against standard financial discussions and theories, behaviors and cognition can affect the financial market and its performance. Such financial decisions and investments are preceded by perceptions and predications and are the effects of emotional and psychological decisions on financial markets. According to Fama (1991) in an efficient market, the prices reflect the existing market news. In efficient market investors make rational decisions and tried to maximize individual profits. The major drawback of efficient market hypothesis is that no one can acquire the complete information of stock market (Hirshleifer, 2001). Moreover, efficient allocation of scare resources and rational decision making are two economic science principles categorized by Simon (1979). The classical theory tries to predict actual behavior of decision making agents. The predictive power of these theories depends on environment and rationality assumptions. Thus, behavioral theories make realistic expectations about human and their abilities as compared to classical theory.

Efficient Market Hypothesis (EMH) was introduced in 1970 by Fama. According to EMH investors should use their private information and ignore past return, however this can be done through 
controlled settings but cannot be in practical life. Investors are not fully rational and their beliefs and emotions always affect the financial assets at risk, which obviously not fully justified by "economic fundamentals", these type of investors are known to be noises traders. The other type of investors are called arbitration, those take full advantage and take rational decisions, but the effectiveness is very limited, because it connects the current investor psychology to finance Thaler and Benartzi (2004). Non-classical financial economists claimed that rational cognition is connected with emotions. Emotions played an important in decision making (Fenton-O'Creevy et al., 2011). Decision making of both experiences and inexperienced investors is affected by these emotions. The less experienced traders showed stronger emotional stimulation during short term market fluctuations.

Similarly, Roger (2011) claimed that according to standard economics theory agents manage information as per Byes rule and take decision without distorting emotions beliefs. Their main objective is to maximize utility as according to expected utility model. Moreover, Etzioni (2014) pointed out that behavioral economics helps in understanding people behavior and intellectual capabilities as they have many cognitive biases which limit their intellectual capabilities. Two psychologists Kahneman and Tversky (1979), also conducted researches on cognition investors, and found that investor's cognitive biases, feelings and attitudes increases by the time and form beliefs and preferences those considered errors in decision making. Such behavior adopted to face a situation resulting, from a weakness in the processing of available information. So behavioral biases form a new pattern of financial decision making which is complements the traditional theory of finance, these biases are the evidence of the existence of irrationality that is related to the process of decision making.

Among these biases are found optimism biases, the representativeness algorithmic, conservatism or mental affix, those affect the financial decision of investors. Investors become overestimate their private information which is basically generated by their own thoughts and abilities, in this type of behavior investors ignores errors or failures, which led them to overestimate the opportunities and abilities. Moreover people always use mental shortcuts instead of using expected utility theory. Economists, psychologists and other researchers tried to study how people make choices for the last many decades. Economics is so different from social sciences due to the assumptions taken in economics that have well defined preferences and make rational choices and as a result behavior can be explained. The study of decision making environment is important for understanding benefit and cost of information for decision making (Ackert et al., 2010). But in reality people do not use expected utility theory as a behavioral guide during high financial rewards decision. Further (Everton et al., 2011) explained the relationship based on assumption of human psychology with modern finance. Modern finance suggests that people make rational decisions and take full advantage of expected utility, but the way people make irrational decisions are against the principle of expected utility. Rational and utility maximizing individuals are known to be positive investment decision makers on the other side decision processes are inclined to several illusions are known to cognitive psychology (Singh, 2012) and (Rehan and Umer, 2017). Study of (Gunay and Demirel, 2011) found that five decision factors (overreaction, herding, cognitive bias, irrational thinking, and overconfidence) influence the decision process of investors.

Investors are usually blamed for their decisions and beliefs for being irrational because they do what majority of people prefer i.e. is "herd instinct" and react too emotionally in stressful situations. And those irrationalities affect ultimately the prices of stock, and create market inefficiencies Hirshleifer et al. (2001). Further Tseng (2006), study shaped the adaptive market hypothesis (which is based on evolutionary biology, information technology, neuro-science, psychology and sociology) by combining the traditional Efficient Market Hypothesis (which supports the idea of a rational investor's behavior) and Behavioral science theory (that includes psychological factors' investigation of decision making under uncertainty). Tseng's aim was to help investors to predict the stock market changes and make better decisions.

Non-classical financial economists claimed that rational cognition is connected with emotions. Emotions played an important in decision making (Fenton-O'Creevy et al., 2011). Decision making 
of both experiences and inexperienced investors is affected by these emotions. Roger (2011) also claimed that according to standard economics theory agents manage information as per byes rule and take decision without distorting emotions beliefs. Furthermore, Etzioni (2014) pointed out that behavioral economics helps in understanding people behavior and intellectual capabilities as they have many cognitive biases which limit their intellectual capabilities.

Some other researchers in this area Tversky and Kahneman (1992) who offered the theory of expectation which helped a lot in developing this science, also Schneider (1992) and Budescu and Weiss (1987) were among the researchers who published articles on financial behavior that played an important role in financial management and have a significant part in guiding investors for tacking financial decisions (Filbeck et al., 2005). Further Thaler (1999) study on literature and concluded that the mental accounting influences the choices. DeBondt and Thaler (1995), found that investors overestimate the chances of accuracy of their information, their successes and capabilities. Shiller (1998), study supported this idea that some individuals underestimate the margin of error likely to be committed and become overconfidence in their judgments while making investments. Further Odean (1999), which states that investors treat first information leading to biased choices, they prefer to maintain their position without concern with profit or loss. In bullish period investors buy more stocks due to the overconfidence and optimum bias, so this bias create inefficiency in the market in the form of mispricing and high volatility (Shah et al., 2013).

Hence, behavioral biases is created due to the wrong interpretation of information available in the market. Individuals use heuristics approach while doing investment. It is important tool and heuristics are strategies for decision making and processing information, because of limited time and information available in the market (Ackert et al., 2010). Hassan et al. (2013) and Rehan and Umer (2017) also conducted a survey study in Pakistan, based on different behavioral biases such as disposition effect, herding, overconfidence and overreaction exist in financial decision making. However, development of literature shows that many behavioral biases are overlapping or extension of other behavioral biases. This study considers only five biases which are frequently observed in financial markets. The above cited literature clearly supports the fact that behavioral biases have impact on investment decision making. There are studies like Pompian (2006) that claimed that behavioral biases have relationship with investor's type. Basically, different investors show different behavioral biases. It is also observes that different investors make financial decision differently. Some investors make rational choices and some investors simply invest on rumor, on advice of others, or hundreds of factors can be listed.

The following conceptual framework and research hypothesis can be drawn from the above literature review.

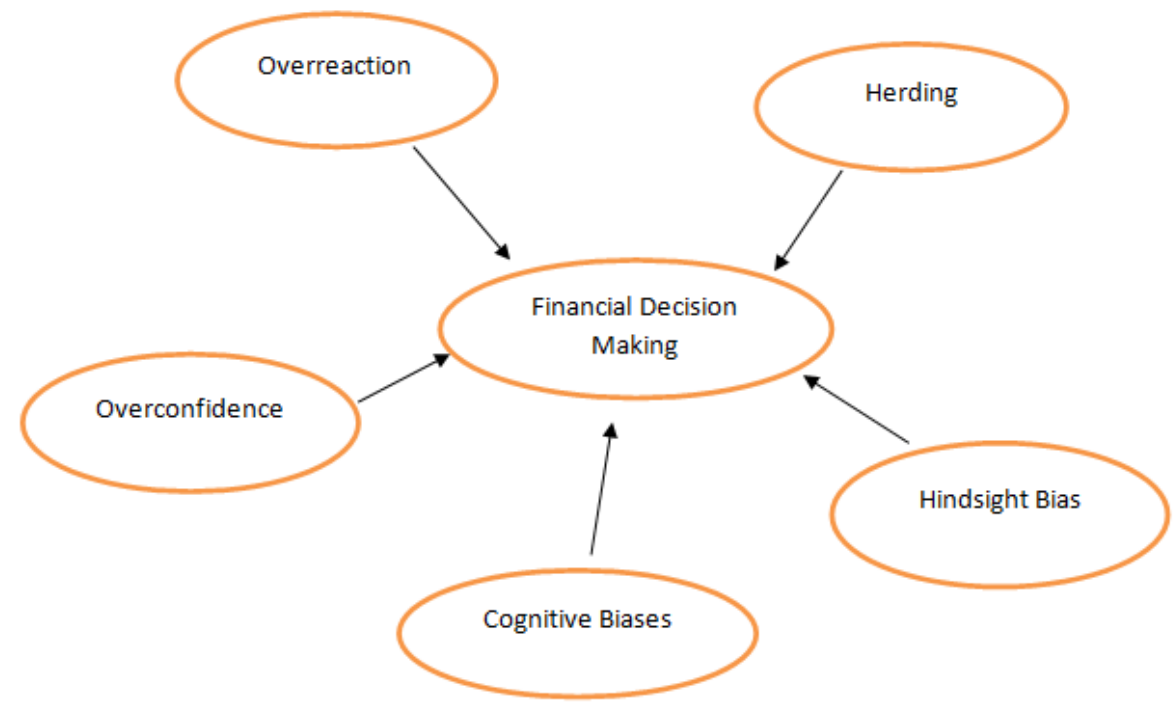


Following alternative hypothesis have been tested:

$\mathrm{H}_{\mathrm{a} 1}$ : there is significant relationship between Behavioral Biases and financial decision making.

$\mathrm{H}_{\mathrm{a} 2}$ : Financial decision making is significantly influenced by overconfidence bias

$\mathrm{H}_{\mathrm{a} 3}$ : Financial decision making is significantly influenced by herding bias

$\mathrm{H}_{\mathrm{a} 4}$ : Financial decision making is significantly influenced by overthinking bias

$\mathrm{H}_{\mathrm{a} 5}$ : Financial decision making is significantly influenced by cognitive bias

$\mathrm{H}_{\mathrm{a} 6}$ : Financial decision making is significantly influenced by hindsight bias

\section{RESEARCH METHODOLOGY}

The philosophical design of the research study is positive paradigm with deductive method and mono methods i.e. quantitative method is used for data analysis. A survey questionnaire is designed and is used as a strategy to collect response. On the time horizon this study is cross sectional study. The behavioral factors are taken as the independent variables and each investment choice is taken as dependent variable. As the population of the study is consisted of investors in Karachi. Express tribune reported that approximately 300,000 people having trading account with the CDC and only about 37000 paid taxes (i.e. capital gain). Therefore, total target population of this study is approximately 37000 investors. Parker and Fischhoff (2005) proposed that at 5\% error margin and $95 \%$ confidence level, sample size should be 385 . Therefore, sample size of this study is 385 . Total 300 questionnaires are received back from respondents and some found unfilled. Therefore, only 241 questionnaires were found useful and selected as sample size. Convenience sampling techniques is used to collect data from investors in PSX. In addition to PSX some other organizations (like brokerage houses, mutual funds and investment management companies) are also visited to collect data from investors.

After the data have been collected the next step in the research process is data analysis. The purpose of this analysis is to interpret and draw conclusions from the collected data. Both descriptive as well as inferential statics are used for data analysis. Twenty seven questions of investor's type are computed through SPSS and the new cumulative score of investor types are generated. Cronbach's Alpha is used to check reliability of data and from 0.70 to 0.90 it is considered as acceptable. Descriptive statistics explained through information available in demographic part of sample. First analysis is done by using T-Test to check whether behavioral biases effect exists in Pakistan or not. Correlation analysis is carried to test relationship behavioral biases and investment decision making. Ordinary least square is used to test influence of behavioral biases (independent variable) and investment decision making (dependent variable). Investor type will take as moderating variable.

\section{RESULTS AND FINDINGS}

There are two types of techniques used for data analysis i.e. descriptive and inferential statistics. Demographic profile of respondents is analyzed through descriptive statistic. To analyze the relationship between behavioral biases and investment decision making, correlation and regression analysis method is used.

\subsection{Validity and reliability}

In order to confirm the validity of questionnaire we first did pilot study, in which thirty respondent's data was analyzed and to check the reliability of the data we applied Cronbach's alpha. The Reliability Analysis showed the value of Cronbach's Alpha $(\alpha)$, which needs to be greater than or equal to 0.6 to conclude the reliability of the survey questionnaire.

Table 1: Reliability statistics

\begin{tabular}{ccc}
\hline Cronbach's Alpha & $\begin{array}{c}\text { Cronbach's Alpha Based } \\
\text { on Standardized Items }\end{array}$ & N of Items \\
\hline 0.852 & 0.850 & 6 \\
\hline
\end{tabular}




\subsection{Respondents' Profile}

Table 2: Respondents' Profile

\begin{tabular}{lcc}
\hline \multicolumn{1}{c}{ Demographic Factors } & Frequency & Percentage \\
\hline Age & & \\
$18-24$ & 80 & 33.2 \\
$24-30$ & 70 & 29.0 \\
$30-36$ & 19 & 7.9 \\
Above 36 & 72 & 29.9 \\
Gender & & \\
Male & 208 & 86.3 \\
Female & 33 & 13.7 \\
Education & & \\
Undergraduate & 60 & 24.9 \\
Graduate & 81 & 33.6 \\
Master & 91 & 37.8 \\
CFA/CIMA/ACCA & 3 & 1.2 \\
Other & 6 & 2.5 \\
Profession & & \\
Business & 125 & 51.9 \\
Salaried & 116 & 48.1 \\
Experience & & \\
Under 3 years & 97 & 40.2 \\
4 -5 years & 32 & 13.3 \\
6 - 10 years & 42 & 17.4 \\
11 - 20 years & 39 & 16.2 \\
20 plus years & 31 & 12.9 \\
\hline
\end{tabular}

\subsection{Correlation analysis}

Table 3: Correlations results

\begin{tabular}{|c|c|c|c|c|c|c|c|}
\hline & & $\begin{array}{l}\text { Financial } \\
\text { Decision } \\
\text { Making } \\
\end{array}$ & $\begin{array}{c}\text { Over- } \\
\text { confidence }\end{array}$ & Herding & Cognitive & $\begin{array}{l}\text { Over- } \\
\text { reaction }\end{array}$ & Hindsight \\
\hline \multirow{3}{*}{$\begin{array}{l}\text { Financial } \\
\text { Decision } \\
\text { Making }\end{array}$} & $\begin{array}{c}\text { Pearson } \\
\text { Correlation }\end{array}$ & 1 & $0.407^{* *}$ & $0.377^{* * *}$ & $0.324^{* *}$ & $0.253^{* *}$ & $0.402^{* *}$ \\
\hline & Sig. (2-tailed) & & 0.000 & 0.000 & 0.000 & 0.000 & 0.000 \\
\hline & $\mathrm{N}$ & 241 & 241 & 241 & 233 & 241 & 239 \\
\hline \multirow{3}{*}{$\begin{array}{l}\text { Over- } \\
\text { confidence }\end{array}$} & $\begin{array}{c}\text { Pearson } \\
\text { Correlation }\end{array}$ & $0.407^{* *}$ & 1 & $0.499^{* *}$ & $0.540^{* *}$ & $0.560^{* *}$ & $0.463^{* *}$ \\
\hline & Sig. (2-tailed) & 0.000 & & 0.000 & 0.000 & 0.000 & 0.000 \\
\hline & $\mathrm{N}$ & 241 & 241 & 241 & 233 & 241 & 239 \\
\hline \multirow{3}{*}{ Herding } & $\begin{array}{c}\text { Pearson } \\
\text { Correlation }\end{array}$ & $0.377^{* *}$ & $0.499^{* *}$ & 1 & $0.613^{* *}$ & $0.596^{* *}$ & $0.606^{* *}$ \\
\hline & Sig. (2-tailed) & 0.000 & 0.000 & & 0.000 & 0.000 & 0.000 \\
\hline & $\mathrm{N}$ & 241 & 241 & 241 & 233 & 241 & 239 \\
\hline \multirow{3}{*}{ Cognitive } & $\begin{array}{c}\text { Pearson } \\
\text { Correlation }\end{array}$ & $0.324^{* *}$ & $0.540^{* *}$ & $0.613^{* *}$ & 1 & $0.616^{* *}$ & $0.533^{* *}$ \\
\hline & Sig. (2-tailed) & 0.000 & 0.000 & 0.000 & & 0.000 & 0.000 \\
\hline & $\mathrm{N}$ & 233 & 233 & 233 & 233 & 233 & 231 \\
\hline $\begin{array}{l}\text { Over- } \\
\text { reaction } \\
\end{array}$ & $\begin{array}{c}\text { Pearson } \\
\text { Correlation } \\
\end{array}$ & $0.253^{* *}$ & $0.560^{* *}$ & $0.596^{* *}$ & $0.616^{* *}$ & 1 & $0.488^{* *}$ \\
\hline
\end{tabular}




\begin{tabular}{cccccccc}
\hline & Sig. (2-tailed) & 0.000 & 0.000 & 0.000 & 0.000 & & 0.000 \\
& $\mathrm{~N}$ & 241 & 241 & 241 & 233 & 241 & 239 \\
& Pearson & $0.402^{* *}$ & $0.463^{* *}$ & $0.606^{* *}$ & $0.533^{* *}$ & $0.488^{* *}$ & 1 \\
Hindsight & Correlation & & & & & \\
& Sig. (2-tailed) & 0.000 & 0.000 & 0.000 & 0.000 & 0.000 & \\
& $\mathrm{~N}$ & 239 & 239 & 239 & 231 & 239 & 239 \\
\hline
\end{tabular}

**. Correlation is significant at the 0.01 level (2-tailed)

The relationship for all the variables is huge. There is strong relationship between the overconfidence and investment decision of investors is 0.60 noteworthy at $1 \%$ level of certainty that shows that if overconfidence of the investors increases it rises the investor decision making for investment. The connection between Herding and decision making for investment is 0.377 critical at $1 \%$ level of certainty which expresses that there is positive relationship between these variables as the Herding bias of the investors increases it increases the investor decision making for investment. The connection between cognitive biases is 0.324 noteworthy at $1 \%$ level of certainty which expresses that there is positive relationship between these variables that shows if cognitive bias rises in investors it increases investor decision making for investment. The connection between overreaction and decision making for investment is 0.253 noteworthy at $1 \%$ level of certainty which expresses that there is positive relationship between these variables as investor overreact towards news/prices it rises its investment decision. The relationship between hindsight bias and decision making for investment is 0.402 noteworthy at $1 \%$ level of certainty which expresses that there is positive relationship between these variables that shows if hindsight bias increases investor make investment decision accordingly.

\subsection{Regression analysis}

Table 4: Regression analysis

\begin{tabular}{ccccc}
\hline Model & R & R Square & Adjusted R Square & Std. Error of the Estimate \\
\hline 1 & $0.486^{\mathrm{a}}$ & 0.236 & 0.219 & 0.6591 \\
\hline
\end{tabular}

. Predictors: (Constant), hindsight, overconfidence, cognitive, overreaction, herding

The analysis shows results of linear regression with investment decision making as dependent variable and five independent variables i.e. overconfidence, herding, overreaction, cognitive bias, and hindsight bias. The results of model summary are evaluated to assess the model fitness. The model summary show that $\mathrm{R}$ Square shows 0.236 variations in investment decision making is explained by the model while adjusted $\mathrm{R}$ squared is 0.219 which is close to $\mathrm{r}$ squared. A high value of R Squared show strong model and $23.6 \%$ predictability level is low. However, this may be due to the other factors not considered in this model.

\subsection{Overall and individual significance}

F-statistics value given below shows the overall fitness of the model and it can be concluded that our model is overall fit as its p-value (sig.) is less than 0.05 .

Table 5: Overall significance

\begin{tabular}{cc}
\hline F & Sig. \\
\hline 13.897 & $0.000^{\mathrm{b}}$ \\
a. Dependent Variable: Financial decision making & \\
b. Predictors: (Constant), hindsight, overconfidence, cognitive, overreaction, herding \\
\hline
\end{tabular}


Table 6: Individual significance

\begin{tabular}{|c|c|c|c|c|c|}
\hline \multirow[t]{2}{*}{ Model } & \multicolumn{2}{|c|}{ Unstandardized coefficients } & \multirow{2}{*}{$\begin{array}{c}\text { Standardized } \\
\text { coefficients } \\
\text { Beta }\end{array}$} & \multirow[t]{2}{*}{$\mathbf{T}$} & \multirow[t]{2}{*}{ Sig. } \\
\hline & B & Std. Error & & & \\
\hline (Constant) & 1.825 & 0.238 & & 7.675 & 0.000 \\
\hline Over-confidence & 0.269 & 0.070 & 0.292 & 3.858 & 0.000 \\
\hline Herding & 0.139 & 0.080 & 0.149 & 1.737 & 0.084 \\
\hline Cognitive & 0.039 & 0.070 & 0.046 & 0.560 & 0.576 \\
\hline Over-reaction & -0.121 & 0.074 & -0.134 & -1.629 & 0.105 \\
\hline Hindsight & 0.193 & 0.075 & 0.200 & 2.560 & 0.011 \\
\hline
\end{tabular}

The result of individual significance test above clearly state that over-confidence and hindsight biases have significant impact on financial decision making of an investor as their significance values are less than 0.05 . The remaining variables i.e. herding, cognitive, overreaction biases have significance value greater than 0.05 indicating that herding, cognitive, overreaction biases do not have any impact on decision making of investors.

\section{CONCLUSION}

Behavioral biases cause mispricing of securities in stock market in a predictable fashion. This study is attempted to determine the role of behavioral biases in investment decision of investor's type in Pakistan Stock Exchange. According to traditional financial theories investors make rational decisions by getting all the information available in the market but financial behavioral theory opposes the concept of traditional theory, because of the psychological factors and their impact on decision making in trading. The result of our study shows that from five independent variables two variables overconfidence and hindsight biases have significant impact on investment decision making with tvalue of $3.858,2.560$ respectively while other variables have no significant impact on investment decision making.

Findings from study will help to identify the impact of behavioral biases exist in financial markets, and try to reduce those biases and make rational decisions while investing in stock for individuals as well as for institutions, which traditional theory suggests. Further the study will also help regulatory authority of market in order to develop such kind of policies to avoid those behavioral biases. Therefore this study will also help researchers and scholars to explore new things in investor's behavior and their impact on decision making in stock market. In this era behavioral finance is emerging field and there are many possible things yet need to explore, which due to limitations we could not explore in our study. This research is limited to Pakistan Stock Exchange only. The results can be varying if the research would be done from over all Pakistan stock markets. Because there are many investment types and types of financial decision making which can affect the results as well Further the sample we have taken in our study is very few in numbers, which can also affect our results.

Many investors invest huge money in stock market in order to gain huge profits in a very short period of time, so behavioral biases increase their behavior and investor's decision affected by these psychological factors. The behavioral biases in financial decision making are known for its irrational behavior of investors, so this kind of behavior can create serious problem like loss of social welfare of investors. As today everyone is much dependent on money so financial decisions are very complex decisions people ever made in their life, and poor financial decisions may result in destruction of human and social life. So we should make efforts in order to reduce those biases. There can be many ways to help investors to make rational financial decisions like by educating and providing trainings to investors. It's a normal phenomenon that many investors who are not so much educated could invest on rumors and advice on other investors instead of their own research and technical analysis. Research culture should be promoted and more investors should be trained in a technical analysis so that they 
can enhance their knowledge in this field and can make rational decisions instead of irrational decisions.

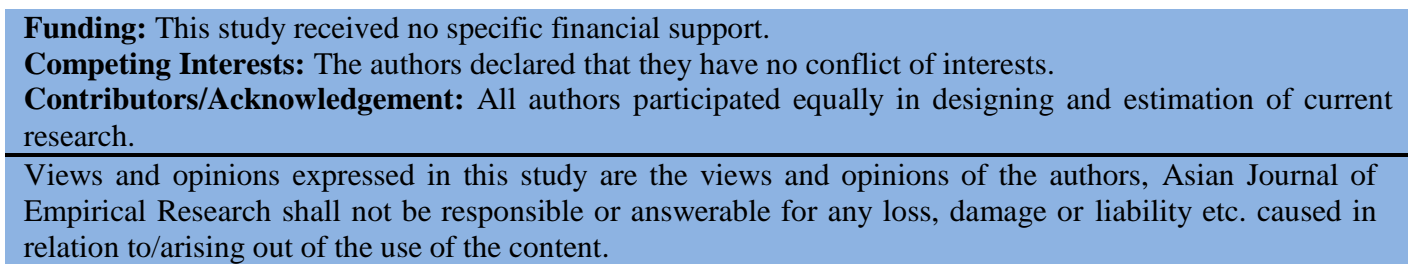

\section{References}

Ackert, L. F., Church, B. K., \& Tkac, P. A. (2010). An experimental examination of heuristic-based decision making in a financial setting. Journal of Behavioral Finance, 11(3), 135-149. view at Google scholar / view at publisher

Babajide, A. A., \& Adetiloye, K. A. (2012). Investors' behavioral biases and the security market: an empirical study of the nigerian security market. Accounting and Finance Research, 1(1), 219229. view at Google scholar / view at publisher

Barberis, N., \& Thaler, R. (2003). A survey of behavioral finance. in G. Constantinides, M. Harris, and R. Stulz (editors) Handbook of the Economics of Finance, North-Holland, Amsterdam. view at Google scholar / view at publisher

Budescu, D. V., \& Weiss, W. (1987). Reflection of transitive and intransitive preferences: a test of prospect theory. Organizational Behavior and Human Decision Processes, 39, 184-202. view at Google scholar / view at publisher

Chang, E. C., Cheng, J. W., \& Khorana, A. (2000). An examination of herd behavior in equity markets: An international perspective. Journal of Banking and Finance, 24(10), 1651-1679. view at Google scholar / view at publisher

DeBondt, W., \& Thaler, R. H. (1995). Financial decision-making in markets and firms: a behavioral perspective. Handbooks in Operations Research and Management Science, 9(13), 385-410. view at Google scholar / view at publisher

DeBondt, Werner, F. M., Mayoral, R. M., \& Vallelado, E. (2013). Behavioral decision-making in finance: an overview and assessment of selected research. Revista Española de Financiación y Contabilidad (Spanish Journal of Finance and Accounting), 42(157), 99-118. view at Google scholar / view at publisher

Etzioni, A. (2014). Humble decision-making theory. Public Management Review, 16(5), 611-619. view at Google scholar / view at publisher

Everton, A. C., Kelmara, M. V., Paulo, S. C., Larissa de Lima, T., \& Carlos, E. M. T. (2011). Misattribution bias: the role of emotion in risk tolerance. The IUP Journal of Behavioral Finance, 8(3), 25-35. view at Google scholar

Fama, E. F. (1991). Efficient capital markets: II. Journal of Finance, 46(5), 1575-1617. view at Google scholar / view at publisher

Fenton-O'Creevy, M., Soane, E., Nicholson, N., \& Willman, P. (2011). Thinking, feeling and deciding: The influence of emotions on the decision making and performance of traders. Journal of Organizational Behavior, 32(8), 1044-1061. view at Google scholar / view at publisher

Filbeck, G., Hatfield, P., \& Horvarth, P. (2005). Risk aversion and personality type. Journal of Behavioral Finance, 6(4), 170-180. view at Google scholar / view at publisher

Gunay, S. G., \& Demirel, E. (2011). Interaction between demographic and financial behavior factors in terms of investment decision making. International Research Journal of Finance and Economics, 66, 147-156. view at Google scholar

Hassan, E. U., Shahzeb, F., Shaheen, M., Abbas, Q., Hameed, Z., \& Hunjra, A. I. (2013). Impact of affect heuristic, fear and anger on the decision making of individual investor: a conceptual study. World Applied Sciences Journal, 23(4), 510-514. view at Google scholar

Hirshleifer, D. (2001). Investor psychology and asset pricing. Journal of Finance, 56(1), 1533-1597. view at Google scholar / view at publisher 
Hirshleifer, D., Daniel, K., \& Subrahmanyam, A. (2001). Overconfidence, arbitrage and equilbrium asset pricing. Journal of Finance 56, 921-965. view at Google scholar / view at publisher

Kahneman, D., \& Tversky, A. (1979). Prospect theory: an analysis of decision under risk. Econometrica, 47(2), 263-291. view at Google scholar / view at publisher

Lin, X., \& Zhang, L. (2012). The investment manifesto. AFA 2013 San Diego Meetings Paper. view at Google scholar

Markowitz, H. (1952). Portfolio selection. Jornal of Finance, 7(1), 77-91. view at Google scholar

Muhammad, N. M. N., \& Abdullah, M. (2009). Investment decision-making style: Are Malaysian investors rational decision makers? Interdisciplinary Journal of Contemporary Research in Business, 1(3), 96-108. view at Google scholar

Odean, T. (1999). Do investors trade too much? American Economic Review, 89(1), 1279-1298. view at Google scholar / view at publisher

Parker, A. M., \& Fischhoff, B. (2005). Decision-making competence: External validation through an individual-differences approach. Journal of Behavioral Decision Making, 18(1), 1-27. view at Google scholar / view at publisher

Pompian, M. (2006). Behavioral finance and wealth management. Hoboken:NJ: John Wiley \& Sons. view at Google scholar

Rehan, R., \& Umer, I. (2017). Behavioural biases and investor decisions. Market Forces, 12(2), 1220. view at Google scholar

Roger, P. (2011). Testing alternative theories of financial decision making: a survey study with lottery bonds. Journal of Behavioral Finance, 12(4), 219-232. view at Google scholar / view at publisher

Schneider, S. (1992). Framing and conflict: aspiration level contingency, the status quo, and current theories of risky choice. Journal of Experimental Psychology: Learning, Memory, and Cognition, 18, 1040-1057. view at Google scholar / view at publisher

Shah, S. F. Raza, M. W., \& Khurshid, M. R. (2013). Overconfidence and perceived market efficiency. Interdisciplinary Journal of Contemporary Research In Business, 3(10), 1018-1026. view at Google scholar

Shefrin, H. (2000). Beyond greed and fear: understanding behavioral finance and the psychology of investing. Boston: Harvard Business School Press. view at Google scholar

Shiller, R. J. (1998). Human behavior and the efficiency of the financial system. National Bureau of Economic, 675, 1-33. view at Google scholar / view at publisher

Shleifer, A., \& Vishny, R. W. (1997). The limits to arbitrage. Journal of Finance, 52(1), 35-55. view at Google scholar / view at publisher

Simon, H. A. (1979). Rational decision making in business organizations. The American Economic Review, 69(4), 493-513. view at Google scholar

Singh, S. (2012). Investor Irrationality and Self-Defeating Behavior: Insights from Behavioral Finance. The Journal of Global Business Management, 8(1), 116-122. view at Google scholar

Statman, M. (2008). What is behavioral finance? handbook of finance. New Jersey: John Wiley \& Sons, Inc., Vol. 2. view at Google scholar

Thaler, R. J. (1999). Mental accounting matters. Journal of Behavioral Decision Making, 12, 183-206. view at Google scholar

Thaler, R., \& Benartzi, S. (2004). Save more tomorrow: using behavioral economics to increase employee savings. Journal of Political Economy, 112, S164-S187. view at Google scholar / view at publisher

Tseng, K. C. (2006). Behavioral finance, bounded rationality, neuro finance and traditional finance. Investment Management and Financial Innovations, 3(4), 7-18. view at Google scholar

Tversky, A., \& Kahneman, D. (1992). Advances in prospect theory: cumulative representation of uncertainty. Journal of Risk and Uncertainty, 5(4), 297-323. view at Google scholar / view at publisher 